\title{
Variation in minerals, polyphenolics and antioxidant activity of pulp, seed and almond of different Ziziphus species grown in Morocco
}

\author{
Variação em minerais, polifenóis e atividade antioxidante da \\ polpa, semente e amêndoa de diferentes espécies do gênero \\ Ziziphus cultivadas no Marrocos
} Ezzouhra El Maaiden ${ }^{1,2 *}$ D, Youssef El Kharrassi ${ }^{2}$, Mouna Lamaoui $^{3}$, Larbi Allai ${ }^{4}$,
Abdel Khalid Essamadi ${ }^{2}$, Boubker Nasser ${ }^{2}$, Khadija Moustaid $^{1}$

${ }^{1}$ University Hassan I, Department of Chemistry, Settat - Morocco

2University Hassan I, Department of Biology, Settat - Morocco

${ }^{3}$ Cadi Ayad University, Department of Biology, Marrakech - Morocco

${ }^{4}$ University Chouaib Doukkali, Department of Biology, El Jadida - Morocco

*Corresponding Author: Ezzouhra El Maaiden, University Hassan I, Department of Chemistry, Laboratory of Applied Chemistry and Environment, BP 577, 26000, Settat - Morocco, e-mail: zohra.elmaaiden@gmail.com

Cite as: El Maaiden, E., El Kharrassi, Y., Lamaoui, M., Allai, L., Essamadi, A. K., Nasser, B., \& Moustaid, K. (2020).

Variation in minerals, polyphenolics and antioxidant activity of pulp, seed and almond of different Ziziphus species grown in Morocco. Brazilian Journal of Food Technology, 23, e2019206. https://doi.org/10.1590/1981-6723.20619

\begin{abstract}
Vegetables from the genus Ziziphus (Rhamnaceae) have been identified as one of the main dietary antioxidants, especially phenolic compounds. However, their chemical composition varies according to the specie or the part of the plant. Mineral composition (potassium, magnesium, calcium, sodium, iron, and zinc), polyphenolic content (Flavan-3-ol, Proanthocyanidin, total polyphenol content) and antioxidant capacity (DPPH, ABTS, and ORAC Assay) in four different matrices (whole fruit, pulp, seed and almond) of Ziziphus (Z. Lotus and Z. Spina Christi) commonly grown in Morocco were investigated. As a result, minerals, polyphenolic contents and antioxidant capacity fluctuated significantly $(p \leq 0.05)$ between different matrices and Ziziphus species analyzed. Seeds displayed a significantly higher mineral level, polyphenolic content and antioxidant capacity in comparison to whole fruit, pulp and almond. Among species, $Z$. spina-christi have a significantly higher content of mineral, phenolics and antioxidant activity. These results suggest that the mineral level, polyphenolic content and antioxidant capacity vary considerably depending on the Ziziphus species and part of the plant analyzed. Furthermore, Z. spina-christi seeds presented properties desirable for use in functional food.
\end{abstract}

Keywords: Ziziphus; Minerals; Proanthocyanidins; Flavan-3-ols; Antioxidant activity.

\section{Resumo}

Vegetais do gênero Ziziphus (Rhamnaceae) têm sido identificados como uma das principais fontes alimentares de antioxidantes, especialmente compostos fenólicos. No entanto, a sua composição química varia de acordo com a espécie ou parte da planta utilizada. Foi avaliada a composição mineral (potássio, magnésio, cálcio, sódio, ferro e 
zinco), o conteúdo polifenólico (Flavan-3-ol, Proantocianidina, conteúdo total de polifenóis) e a capacidade antioxidante (ensaios DPPH, ABTS e ORAC) em quatro matrizes (fruta inteira, polpa, semente e amêndoa) de diferentes espécies de Ziziphus (Z. Lotus e Z. Spina Christi), geralmente cultivadas em Marrocos. Minerais, conteúdo polifenólico e capacidade antioxidante variaram significativamente $(p \leq 0,05)$ em função das matrizes e das espécies analisadas. Em relação às diferentes matrizes, as sementes apresentaram conteúdo mineral, polifenólicos e capacidade antioxidante em teores significativamente mais elevados que o fruto inteiro, a polpa e a amêndoa. Entre as espécies, Z. Spina Christi tem um conteúdo significativamente maior de minerais, fenólicos totais e antioxidantes. Estes resultados sugerem que o conteúdo mineral, de polifenólicos e de antioxidantes varia consideravelmente dependendo da espécie de Ziziphuse e da matriz analisada. Ademais, sementes de Z. Spina Christi apresentaram propriedades desejáveis para utilização em alimentos funcionais.

Palavras-chave: Ziziphus; Minerais; Proantocianidinas; Flavan-3-ols; Atividade antioxidante.

\section{Introduction}

Ziziphus (Rhamnaceae) is a widespread genus in the tropical and subtropical regions of Asia, Africa, North America, South America and Europe (Adeli \& Samavati, 2015). Although there are around 170 types of Ziziphus around the world, just two species Z. Lotus and Z. Spina Christi are found in Morocco. Z. Lotus normally called Sedra is a prickly bush that spans up to 2 meters high. It yields small and freshly consumed fruits called the jujube and locally "n'beg". In addition, Z. Lotus is broadly used in the folk medicine for the treatment of different sicknesses such as bronchitis, diarrhea, abscess, liver problem, insomnia, inflammation and diabetes (Adzu et al., 2003). Z. Spina Christi, which is known as Christi's thorn or Jerusalem thorn in English and Sidr in Arabic, is a tropical tree of Sudanese origin reaching a height of 20 meters (Zargari, 1988). It has oval fruits, which are different from those of $Z$. lotus, are equally used in the folk medicine for the management of pain, diabetes and other inflammatory-related problems (Kadioglu et al., 2016).

The antioxidants are potential protective agents that reduce significantly the oxidative damage in the human body to recover any ineffectiveness of the enzymatic mechanisms (Halliwell, 1995). Butylated hydroxyanisole (BHA) and butylated hydroxytoluene (BHT), the most common synthetic antioxidants, is fortified as fat and oily food additives to prevent oxidative deterioration ( $\mathrm{Li}$ et al., 2008). Due to their reported side effects, such as carcinogenicity, recent restrictions have been raised and attention has been redirected toward the natural antioxidants for food and/or medicinal industries).

Main minerals are very important in biological processes, play a vital role in the prevention of some chronic diseases (Gorinstein et al., 2001). That is why mineral content in food potentially useful as supplementary information to current food composition. The available information on the minerals and antioxidant properties of Z. Spina Christi and Z. Lotus pulp and seed are sporadic. Also, to the best of our understanding, no previous studies have documented the minerals and antioxidant activity of the almond of Ziziphus sp., so the main objective of this investigation was to compare the minerals (potassium, magnesium, calcium, sodium, iron, and zinc), polyphenolic contents (total phenols, flavan-3-ols, and proanthocyanidins) and antioxidant activities (DPPH, ABTS, and oxygen radical absorbance) between whole fruit, pulp, seed and almonds of Ziziphus sp. grown in Morocco.

\section{Material and methods}

\subsection{Plant material and sample preparation}

Ripened fruits of Z. Spina Christi and Z. Lotus were collected from the field in Settat and Khouribga cities of Morocco (32 $52^{\prime} 49.3^{\prime \prime} \mathrm{N}^{\circ} 46^{\prime} 10.5^{\prime \prime} \mathrm{W}, 3^{\circ} 03^{\prime} 49.6^{\prime \prime} \mathrm{N} 7^{\circ} 37^{\prime} 24.7^{\prime \prime} \mathrm{W}$ respectively), between November and December 2018. The plant material was identified through morphological and botanical traits. After harvest, 
the fruits were cleaned with water and carefully separated into pulps, seeds and almonds using a stainless-steel knife dried shade; powdered in a heavy-duty grinder and packaged separately in airtight containers at room temperature $\left(24 \pm 4{ }^{\circ} \mathrm{C}\right)$, until use.

We mixed $100 \mathrm{~g}$ of each powder with $250 \mathrm{~mL}$ of double-distilled water (ddH2O). The mixture was subjected to a hot and continuous extraction in the Soxhlet apparatus (reflux conditions). Extracts were filtered and evaporated under low pressure to give a viscous mass with a percentage yield of $5 \%$ to $20 \%$ $(\mathrm{w} / \mathrm{w})$. The concentrated crude extracts were stored at $4{ }^{\circ} \mathrm{C}$ until being used polyphenolic and antioxidant activities analysis (Elmaaiden et al., 2019).

\subsection{Mineral and trace elements content}

Minerals analysis was performed according to the methods described by the Association of Official Analytical Chemists (1990). Briefly, $1 \mathrm{~g}$ of dried samples was ashed in a muffle furnace $\left(550 \pm 10{ }^{\circ} \mathrm{C}, 6 \mathrm{~h}\right)$ then digested with $5 \mathrm{~mL}$ of $\mathrm{HCl}(6 \mathrm{M})$ in a water bath. After drying, $7 \mathrm{~mL}$ of $\mathrm{HNO} 3(0.1 \mathrm{M})$ was added and the contents were diluted to $100 \mathrm{~mL}$ with double-deionized water. Potassium (K) was done on a flame photometer (Systronics-130) whereas magnesium $(\mathrm{Mg})$, calcium $(\mathrm{Ca})$, sodium $(\mathrm{Na})$, iron $(\mathrm{Fe})$, and zinc $(\mathrm{Zn})$ were determined on an atomic absorption spectrophotometer (ECIL Atomic Absorption Spectrophotometer-4141). Standard calibration curves were constructed for each element individually utilizing linear correlation by the least square method after running standard solutions. The blank reading was used to make necessary corrections during the calculation of elemental concentrations.

\subsection{Plyphenolic content}

Total phenolic content (TPC) was determined by the Folin-Ciocalteu's reagent according to the method of Laličić-Petronijević et al. (2016). Briefly, $0.25 \mathrm{~mL}$ of Folin reagent (diluted 10 times) was added to $0.25 \mathrm{~mL}$ of the sample with appropriate dilutions and $2 \mathrm{~mL}$ of a solution of sodium carbonate (7.5\%). The reaction mixture was incubated at room temperature for $30 \mathrm{~min}$ with intermittent shaking for color development. The absorbance of the resulting blue color was measured at $765 \mathrm{~nm}$ using a double-beam UV-Vis spectrophotometer. Gallic acid was used as the standard. All measurements were performed in triplicate. Results were expressed as mg of gallic acid equivalent per gram of dry weight (mg GAE/g DW).

Total proanthocyanidin content (TPAC) were determined by the Bate-Smith method, described by Laličić-Petronijević et al. (2016). Briefly, $0.2 \mathrm{~mL}$ of each sample was mixed with $20 \mathrm{~mL}$ of butanol/HCl (50:50) and $0.54 \mathrm{mM} \mathrm{FeSO}$. The mixture was incubated at $90^{\circ} \mathrm{C}$ for $1 \mathrm{~h}$ and after cooling, the volume was completed to $25 \mathrm{~mL}$ with the butanol- $\mathrm{HCl}$ mixture. The absorbance was measured at $550 \mathrm{~nm}$ against a blank prepared in a similar way but without heating. The standard used was cyanidin chloride (which served to draw a calibration curve. All measurements were performed in triplicate. Results were expressed as mg of cyanidin chloride equivalent per gram of dry weight (mg CCE/g DW).

Total Flavan-3-ol content (TFC) were determined by the vanillin assay using the daily prepared working solution of $4 \%$ vanillin in methanol according to the method of Laličić-Petronijević et al. (2016). The content of flavan-3-ol was calculated according to Equation 1:

$\omega($ flavon $-3-\mathrm{ol})=290 . \mathrm{x} \Delta \mathrm{A}$

where $\Delta A$ is the difference by subtracting the absorbance (550) of the blank from the absorbance of the corresponding vanillin-containing sample. All measurements were performed in triplicate. Results were expressed as mg of (+)-catechin equivalent per gram of dry weight (mg CE/g DW). 


\subsection{Antioxidant activity}

1,1-Diphenyl-2-picrylhydrazyl (DPPH) radical scavenging assay was performed based on the procedure described by Zakaria et al. (2008). Briefly, $0.4 \mathrm{~mL}$ of the diluted sample solution and $2 \mathrm{~mL}$ of DPPH-methanolic solution $(0.1 \mathrm{mM})$ were mixed and the obtained mixture was placed at room temperature in the dark for $30 \mathrm{~min}$. The absorbance (abs) was subsequently measured at $517 \mathrm{~nm}$ by spectra ax M5 microplate reader (Molecular Devices, America). Vitamin C was used as a positive control. All measurements were performed in triplicate. DPPH was expressed as the inhibition percentage of DPPH radical and was calculated following the Equation 2:

DPPH radical scavening activity $(\%)=\left[\frac{(\text { Abs Control }- \text { Abs Sample })}{(\text { Abs Control })}\right] \times 100$

2,2'-azino-bis (3-ethylbenzothiazoline-6-sulphonic acid) (ABTS) assay was realized as described by Ammar et al. (2015). The stock solution of the ABTS radical was produced by reacting $10 \mathrm{~mL}$ of ABTS $(2 \mathrm{mM})$ with $0,1 \mathrm{~mL}$ of potassium persulphate $(70 \mathrm{mM})$ and allowing the mixture to stand in the dark at room temperature for $16 \mathrm{~h}$. The ABTS radical working solution was diluted with phosphate-buffered saline (PBS, pH 7.4) to an absorbance of $0.70( \pm 0.02)$ at $734 \mathrm{~nm}$. All measurements were performed in triplicate. The samples were prepared by diluting $0,1 \mathrm{~mL}$ of dried extracts in $2 \mathrm{~mL}$ of the diluted ABTS + solution; the mixture is left for 1 minute so that the reaction can be carried out. The absorbance is recorded on a spectrophotometer at $734 \mathrm{~nm}$. The ABTS radical-scavenging activity of the extract was calculated from the calibration curve of Trolox and expressed as mg Trolox equivalent per gram of dried weight (mg TE/g DW).

Oxygen Radical Absorbance Capacity (ORAC) assay was conducted on an automated plate reader with 96-well plates following the method of Prior et al. (2003). Analyses were conducted in phosphate buffer $\left(7.4 \mathrm{pH}, 37^{\circ} \mathrm{C}\right)$. Peroxyl radical was generated using 2, 2'-azobis (2-amidinopropane) dihydrochloride prepared freshly for each run. Fluorescein was used as the excitation at $485 \mathrm{~nm}$ and emission at $520 \mathrm{~nm}$. All measurements were performed in triplicate. The results were expressed as mg Trolox equivalent per gram of dry weight (mg TE/g DW).

\subsection{Data analysis}

All data were expressed as means the standard deviation $(n=3)$. Statistical analyses were performed with SPSS (SPSS Inc. Chicago, IL, IL, USA; version 21). The data were analyzed by an analysis of variance and the significance of the difference between sample means was calculated by Student Newman Keuls test ( $p<0.05$ was regarded as significant and $p<0.005$ as very significant).

\section{Results and discussion}

\subsection{Mineral composition}

Minerals assume a key role in different physiological functions of the body, particularly in the regulation of process and building (Yasser et al., 2010).

Results of the mineral profile are shown in Table 1. The contents of most evaluated elements varied significantly according to the fruit tissue and specie evaluated. Independently of the fruit tissue, results showed greater variation amongst the different Ziziphus sp. analyzed. Among species, Z. spina christi had the highest mineral content. Regarding the different fruit tissues, the seeds exhibited the highest contents of $\mathrm{K}, \mathrm{Mg}, \mathrm{Ca}$ and $\mathrm{Na}$ (203.20 to $179.65,78.37$ to $74.80,73.53$ to 68.69 and 33.70 to $22.77 \mathrm{mg} / 100 \mathrm{~g}$ respectively). Similar results were reported by Djemai (2009), who determined that seed of Z. lotus contains a higher amount of minerals compared to pulp. 
Table 1. Mineral contents of Z. Lotus (ZL) and Z. spina Christi (ZSC) whole fruit, pulp, seed and almond (mg/100 g of dry weight).

\begin{tabular}{cccccccc}
\hline & $\begin{array}{c}\text { Potassium } \\
(\mathbf{K})\end{array}$ & $\begin{array}{c}\text { Calcium } \\
(\mathbf{C a})\end{array}$ & $\begin{array}{c}\text { Magnesium } \\
(\mathbf{M g})\end{array}$ & $\begin{array}{c}\text { Sodium } \\
(\mathbf{N a})\end{array}$ & $\begin{array}{c}\text { Iron } \\
(\mathbf{F e})\end{array}$ & $\begin{array}{c}\text { Zinc } \\
(\mathbf{Z n})\end{array}$ \\
\hline \multirow{4}{*}{ ZSC } & Fruit & $110.87 \pm 6.71^{\mathrm{a}}$ & $63.26 \pm 1.63^{\mathrm{b}}$ & $63.83 \pm 0.36^{\mathrm{a}}$ & $20.43 \pm 0.94^{\mathrm{b}}$ & $0.26 \pm 0.02^{\mathrm{b}}$ & $0.44 \pm 0.06^{\mathrm{a}}$ \\
\cline { 2 - 8 } & Pulp & $78.90 \pm 0.67^{\mathrm{b}}$ & $77.70 \pm 0.67^{\mathrm{a}}$ & $58.07 \pm 0.58^{\mathrm{a}}$ & $18.23 \pm 0.49^{\mathrm{bc}}$ & $0.22 \pm 0.06^{\mathrm{ab}}$ & $0.38 \pm 0.03^{\mathrm{b}}$ \\
\cline { 2 - 8 } & Seed & $203.20 \pm 3.33^{\mathrm{a}}$ & $78.37 \pm 0.23^{\mathrm{ab}}$ & $73.53 \pm 0.29^{\mathrm{a}}$ & $33.70 \pm 0.15^{\mathrm{b}}$ & $0.75 \pm 0.18^{\mathrm{c}}$ & $0.65 \pm 0.04^{\mathrm{bd}}$ \\
\cline { 2 - 8 } & Almond & $138.90 \pm 0.67^{\mathrm{b}}$ & $52.23 \pm 1.90^{\mathrm{b}}$ & $63.57 \pm 0.44^{\mathrm{c}}$ & $19.62 \pm 0.16^{\mathrm{bc}}$ & $0.90 \pm 0.01^{\mathrm{ab}}$ & $0.86 \pm 0.05^{\mathrm{ab}}$ \\
\hline \multirow{4}{*}{$\mathbf{Z L}$} & Fruit & $78.57 \pm 0.44^{\mathrm{b}}$ & $63.26 \pm 1.63^{\mathrm{b}}$ & $60.80 \pm 1.33^{\mathrm{a}}$ & $18.50 \pm 0.67^{\mathrm{c}}$ & $0.16 \pm 0.13^{\mathrm{c}}$ & $0.31 \pm 0.01^{\mathrm{a}}$ \\
\cline { 2 - 8 } & Pulp & $65.73 \pm 1.11^{\mathrm{b}}$ & $70.40 \pm 0.67^{\mathrm{b}}$ & $51.20 \pm 0.67^{\mathrm{a}}$ & $8.93 \pm 0.64^{\mathrm{bc}}$ & $0.11 \pm 0.40^{\mathrm{b}}$ & $0.28 \pm 0.06^{\mathrm{d}}$ \\
\cline { 2 - 8 } & Seed & $179.60 \pm 0.10^{\mathrm{a}}$ & $74.80 \pm 0.67^{\mathrm{b}}$ & $68.69 \pm 0.14^{\mathrm{a}}$ & $22.77 \pm 0.84^{\mathrm{c}}$ & $0.50 \pm 0.01^{\mathrm{c}}$ & $0.59 \pm 0.04^{\mathrm{bd}}$ \\
\cline { 2 - 8 } & Almond & $89.52 \pm 0.11^{\mathrm{a}}$ & $45.17 \pm 0.89^{\mathrm{a}}$ & $62.76 \pm 0.05^{\mathrm{b}}$ & $10.63 \pm 0.66^{\mathrm{a}}$ & $0.70 \pm 0.03^{\mathrm{cd}}$ & $0.78 \pm 0.04^{\mathrm{c}}$ \\
\hline
\end{tabular}

Values represent the mean \pm standard deviation $(\mathrm{n}=3)$. Different letters in the same column mean significant difference $\left(p<0.05\right.$ : ${ }^{\mathrm{a}}$ and $p<0.005$ : ab) by the Student Newman Keuls test between the same botanical parts for each species.

While the content of Fe and $\mathrm{Zn}$ were found to be highest in the almonds $(0.70-0.90$ and $0.78-0.86 \mathrm{mg} / 100 \mathrm{~g})$ for Z. spina christi and Z. Lotus respectively.

Several factors, such as variety, soil state, irrigation regime, harvest time, maturation, storage conditions, state of ripeness, may cause variation in the mineral contents in various sorts of fruits as well as within different parts of the same fruit (Leterme et al., 2006).

\subsection{Polyphenolic contents}

Polyphenolics are one of the major bio-compounds acting as primary antioxidants. Therefore, it is worthwhile to determine their total amount within the species subject of our study. Total phenolic (TPC), proanthocyanidin (TPAC), and flavan-3-ol content (TFC) in each fruit tissue of Z. Lotus (ZL) and Z. spina Christi (ZSC) are summarized in Table 2. The obtained results reveal that the content of the polyphenol fluctuates significantly $(p<0.05)$ depending on the botanical parts and the species subject of study. In term of Ziziphus sp. analyzed, Z. spina christi exhibited notable polyphenolic contents compared to Z. lotus. Regarding the different fruit tissues, the seeds of both species $Z S C$ and $Z L$ revealed the highest average values of TPC (30.24-24.46 mg GAE/gDW), TPAC (22.98-18.88 mg CCE/gDW), TFC (6.43-5.85 mg CE/gDW), while the pulp extracts contain clearly the lowest content of TPC (18.80-20.97 mg GAE/gDW), TPAC (11.09 -7.88 mg CCE/gDW), TFC (4.89-2.10 mg CE/gDW) for ZSC and ZL respectively. It should be noted that determination of polyphenolic contents can be influenced by the method employed, the solvent used, the nature of the compound, sample size, time and storage conditions, reference standard used and interfering elements (Bucić-Kojić et al., 2009).

Table 2. Polyphenolic contents including total phenolic, proanthocyanidin and flavan-3-ol content of fruit tissues for Z. Lotus (ZL) and Z. spina Christi (ZSC).

\begin{tabular}{|c|c|c|c|c|c|c|}
\hline & \multicolumn{2}{|c|}{ TPC (mg GAE/g DW) } & \multicolumn{2}{|c|}{ TPAC (mg CCE/g DW) } & \multicolumn{2}{|c|}{ TFC (mg CE/g DW) } \\
\hline & $\overline{Z S C}$ & $Z L$ & $\overline{Z S C}$ & $Z L$ & $\overline{Z S C}$ & $Z L$ \\
\hline Whole fruit & $26.33 \pm 0.07^{\mathrm{ab}}$ & $22.00 \pm 0.15^{\mathrm{ab}}$ & $12.66 \pm 0.10^{a b c}$ & $8.12 \pm 0.09^{\mathrm{abc}}$ & $4.74 \pm 0.12^{\mathrm{ab}}$ & $5.49 \pm 0.10^{\mathrm{ab}}$ \\
\hline Pulp & $18.80 \pm 0.08^{\mathrm{ab}}$ & $20.97 \pm 0.07^{\mathrm{ab}}$ & $11.09 \pm 0.03^{\mathrm{abc}}$ & $7.88 \pm 0.09^{\mathrm{abc}}$ & $4.89 \pm 0.08^{\mathrm{ab}}$ & $2.10 \pm 0.10^{\mathrm{ab}}$ \\
\hline Seed & $30.24 \pm 0.1^{\mathrm{a}}$ & $24.46 \pm 0.08^{\mathrm{ab}}$ & $22.98 \pm 0.14^{\mathrm{a}}$ & $18.88 \pm 0.11^{\mathrm{a}}$ & $6.43 \pm 0.09^{a}$ & $5.85 \pm 0.11^{\mathrm{a}}$ \\
\hline Almond & $21.40 \pm 0.02^{\mathrm{ab}}$ & $21.05 \pm 0.06^{\mathrm{ab}}$ & $17.20 \pm 0.10^{\mathrm{ab}}$ & $14.66 \pm 0.08^{\mathrm{ab}}$ & $4.99 \pm 0.11^{\mathrm{ab}}$ & $3.65 \pm 0.10^{\mathrm{abc}}$ \\
\hline
\end{tabular}

Results expressed as mean \pm standard deviation $(\mathrm{n}=3)$. Different letters in the same column mean significant difference $\left(p<0.05:{ }^{\mathrm{a}}\right.$ and $p<0.005$ : ab) by the Student-Newman-Keuls test between the same botanical parts for each species. TPC: Total phenolic content, TFC: Total Flavan-3-ol content, TPAC: Total proanthocyanidin content.

\subsection{Antioxidant activity}

The antioxidant properties are extremely complex. Therefore, the use of more than one method is essential for acquiring reliable results. In our study tree assays were used to assess the total antioxidant capacity of fruit tissues from Ziziphus sp. (DPPH, ABTS, and ORAC assay). The DPPH test is based on the reaction of 
the antioxidants with the stable free radical. $\alpha$-diphenyl- $\beta$-picrylhydrazyl, which have a deep violet color producing a less colored compound which is $\alpha$-diphenyl- $\beta$-picrylhydrazine. ABTS is another synthetic radical more versatile than DPPH as it can assess the scavenging activity for both the polar and non-polar extracts (Re et al., 1999). ORAC measures include all the traditional antioxidants counting the hydrophilic and lipophilic (Cao et al., 1997).

The antioxidant capacity of whole fruit, pulp, seed and almond of Ziziphus sp., are shown in Table 3. DPPH, ABTS and ORAC value was significantly different depending on the Ziziphus sp. and the fruit tissue evaluated. Z. spina christi showed a significantly higher antioxidant capacity than $Z$. lotus. Regarding the different fruit tissue seed of two species exhibited a remarkable antioxidant activity, DPPH (64.87 to $48.28 \%$ ), ABTS ( 75.87 to $33.60 \mathrm{mg}$ TE/g DW), ORAC (20.94 to $17.1 \mathrm{mg} \mathrm{TE} / \mathrm{g} \mathrm{DW}$ ) for ZSC and $\mathrm{ZL}$ respectively, compared to the other fruit tissues.

Table 3. Antioxidant activities of fruit tissues for Z. Lotus (ZL) and Z. spina Christi (ZSC) determined by the DPPH, ABTS and ORAC assay.

\begin{tabular}{|c|c|c|c|c|c|c|}
\hline & \multicolumn{2}{|c|}{ DРPH\% } & \multicolumn{2}{|c|}{ ABTS (mg TE/g DW) } & \multicolumn{2}{|c|}{ ORAC (mg TE/g DW) } \\
\hline & $Z S C$ & $Z L$ & $Z S C$ & $Z L$ & $Z S C$ & $Z L$ \\
\hline Whole fruit & $51.98 \pm 0.31 \mathrm{ab}$ & $61.91 \pm 0.85^{\mathrm{a}}$ & $23.56 \pm 0.28 \mathrm{abc}$ & $18.38 \pm 0.20 \mathrm{abc}$ & $13.88 \pm 0.23 \mathrm{ab}$ & $13.06 \pm 0.05 \mathrm{ab}$ \\
\hline Pulp & $35.74 \pm 0.70 \mathrm{abc}$ & $33.65 \pm 0.21^{\mathrm{abc}}$ & $24.78 \pm 0.21 \mathrm{abc}$ & $19.6 \pm 0.17 \mathrm{abc}$ & $12.10 \pm 0.35^{\mathrm{ab}}$ & $10.53 \pm 0.24 \mathrm{abc}$ \\
\hline Seed & $64.87 \pm 1.42^{a}$ & $48.28 \pm 0.41 \mathrm{ab}$ & $75.87 \pm 0.36^{\mathrm{a}}$ & $33.60 \pm 0.21 \mathrm{abc}$ & $20.94 \pm 0.46^{\mathrm{a}}$ & $17.1 \pm 0.15^{\mathrm{a}}$ \\
\hline Almond & $55.88 \pm 0.72 \mathrm{ab}$ & $26.36 \pm 0.28 \mathrm{abc}$ & $65.84 \pm 0.90^{\text {a }}$ & $26.36 \pm 0.28 \mathrm{abc}$ & $15.91 \pm 0.27 \mathrm{ab}$ & $14.76 \pm 0.12 \mathrm{ab}$ \\
\hline
\end{tabular}

All values are presented as the means \pm standard deviation. Different letters in the same column mean significant difference $(p<0.05$ : a and $p<0.005:$ ab) by the Student-Newman-Keuls test between the same botanical parts for each species. DPPH: 1, 1-Diphenyl-2-picrylhydrazyl, ABTS: assay, 2'-azino-bis (3-ethylbenzothiazoline-6-sulphonic acid), ORAC: Oxygen radical absorbance capacity.

\section{Conclusion}

In the present study, the minerals, polyphenolic contents and antioxidant activities of different fruit tissues (whole fruit, pulp, seed and almond) of tow locally available species of Ziziphus fruit from Morocco were evaluated. Among the tow species analyzed, Z. Spina Christi exhibited higher mineral, polyphenolic contents and antioxidant activity compared to Z. Lotus. Besides, the present results also revealed that Ziziphus seed exhibited higher mineral, polyphenolic contents and antioxidant activity compared to that of whole fruit, pulp and almond, indicating that removal of seed from such fruits may induce significant nutrient losses. Therefore, the Ziziphus sp. seeds could be used for functional foods. However, further research trials are required to isolate the main constituents responsible for the antioxidant nature and biological activities for further applications in the food and pharmaceutical industries.

\section{Acknowledgements}

Authors thank Dr. Gérard Lizard director of Bio-PeroxIL Laboratory, University of Bourgogne, France, for the discussion and the careful reading of the manuscript. The help in redaction of abstract in Portuguese by Nilson César Castanheira Guimarães, federal inspector of agriculture/agricultural attaché and Brazilian Embassy in Rabat - Kingdom of Morocco is duly acknowledged.

\section{References}

Adeli, M., \& Samavati, V. (2015). Studies on the steady shear flow behavior and chemical properties of water-soluble polysaccharide from Ziziphus lotus fruit. International Journal of Biological Macromolecules, 72, 580-587. PMid:25195543. http://dx.doi.org/10.1016/j.ijbiomac.2014.08.047

Adzu, B., Amos, S., Amizan, M. B., \& Gamaniel, K. (2003). Evaluation of the antidiarrhoeal effects of Zizyphus spina-christi stem bark in rats. Acta Tropica, 87(2), 245-250. PMid:12826300. http://dx.doi.org/10.1016/S0001-706X(03)00114-1

Ammar, I., Ennouri, M., \& Attia, H. (2015). Phenolic content and antioxidant activity of cactus (Opuntia ficus-indica L.) flowers are modified according to the extraction method. Industrial Crops and Products, 64, 97-104.

http://dx.doi.org/10.1016/j.indcrop.2014.11.030 
Association of Official Analytical Chemists - AOAC. (1990). Official methods of analysis (Vol. 1). Gaithersburg: AOAC.

Bucić-Kojić, A., Planinić, M., Tomas, S., Jakobek, L., \& Šeruga, M. (2009). Influence of solvent and temperature on extraction of phenolic compounds from grape seed, antioxidant activity and colour of extract. International Journal of Food Science \& Technology, 44(12), 2394-2401. http://dx.doi.org/10.1111/j.1365-2621.2008.01876.x

Cao, G., Sofic, E., \& Prior, R. L. (1997). Antioxidant and prooxidant behavior of flavonoids. structure-activity relationships. Free Radical Biology \& Medicine, 22(5), 749-760. PMid:9119242. http://dx.doi.org/10.1016/S0891-5849(96)00351-6

Djemai, Z.S. (2009). Etude de l'activité biologique des extraits du fruit de Zizyphus Lotus L. (Mémoire de master). Université El HadjLakhdar, Batna.

El Maaiden, E., El Kharrassi, Y., Moustaid, K., Essamadi, A. K., \& Nasser, N. (2019). Comparative study of phytochemical profile between Ziziphus spina christi and Ziziphus lotus from Morocco. Food Measure, 13(1), 121-130. http://dx.doi.org/10.1007/s11694-018-9925-y

Gorinstein, S., Zachwieja, M., Folta, M., Barton, H., Piotrowicz, J., Zemser, M., Weisz, M., Trakhtenberg, S., \& Màrtín-Belloso, O. (2001). omparative contents of dietary fiber. total phenolics. and minerals in persimmons and apples. Journal of Agricultural and Food Chemistry, 49(2), 952-957. PMid:11262055. http://dx.doi.org/10.1021/jf000947k

Halliwell, B. (1995). Antioxidant characterization: Methodology and mechanism. Biochemical Pharmacology, 49(10), 1341-1348. PMid:7763275. http://dx.doi.org/10.1016/0006-2952(95)00088-H

Kadioglu, O., Jacob, S., Bohnert, S., Naß, J., Saeed, M. E., Khalid, H., Merfort, I., Thines, E., Pommerening, T., \& Efferth, T. (2016). Evaluating ancient Egyptian prescriptions today: Anti-inflammatory activity of Ziziphus spina-christi. Phytomedicine, 23(3), 293-306. PMid:26969383. http://dx.doi.org/10.1016/j.phymed.2016.01.004

Laličić-Petronijević, J., Komes, D., Gorjanović, S., Belščak-Cvitanović, A., Pezo, L., Pastor, F., Ostojić, S., Popov-Raljić, J., \& Sužnjević, D. (2016). Content of total phenolics, flavan-3-ols and proanthocyanidins, oxidative stability and antioxidant capacity of chocolate during storage. Food Technology and Biotechnology, 54(1), 13-20. PMid:27904388.

Leterme, P., Buldgen, A., Estrada, F., \& Londoño, A. M. (2006). Mineral content of tropical fruits and unconventional foods of the Andes and the rain forest of Colombia. Food Chemistry, 95(4), 644-652. http://dx.doi.org/10.1016/j.foodchem.2005.02.003

Li, H. B., Wong, C. C., Cheng, K. W., \& Chen, F. (2008). Antioxidant properties in vitro and total phenolic contents in methanol extracts from medicinal plants. Lebensmittel-Wissenschaft + Technologie, 41(3), 385-390. http://dx.doi.org/10.1016/j.Iwt.2007.03.011

Prior, R., Hoang, H., Gu, L., Wu, X., Bacchiocca, M., Howard, L., Hampsch-Woodill, M., Huang, D., Ou, B., \& Jacob, R. (2003). Assays for hydrophilic and lipophilic antioxidant capacity (Oxygen Radical Absorbance Capacity (ORAC FL)) of plasma and other biological and food samples. Journal of Agricultural and Food Chemistry, 51(11), 3273-3279. PMid:12744654. http://dx.doi.org/10.1021/j0262256

Re, R., Pellegrini, N., Proteggente, A., Pannala, A., Yang, M., \& Rice-Evans, C. (1999). Antioxidant activity applying an improved ABTS radical cation decolorization assay. Free Radical Biology \& Medicine, 26(9-10), 1231-1237. http://dx.doi.org/10.1016/S0891-5849(98)00315-3

Yasser, D., Ayub, M., Ali, M., \& Asad, A. (2010). Physicochemical response of apple pulp to chemical preservatives and antioxidant during storage. Internet Journal of Food Safety, 12, 20-28.

Zakaria, Z., Aziz, R., Yoga, L., Sreenivasan, S., \& Rathinam, X. (2008). Antioxidant activity of Coleus blumei, Orthosiphon stamineus, Ocimum basilicum and Mentha arvensis from Lamiaceae Family. International Journal of Natural Sciences, 2, 93-95. Zargari, A. (1988). Medicinal plants. Tehran: Tehran University of Medical Sciences.

Funding: None. 